DIMENSI, VOL. 8, NO. 2 : 240-248

JULI 2019

ISSN: 2085-9996

\title{
PENGARUH PELATIHAN TERHADAP KINERJA KARYAWAN
}

\author{
THE EFFECT OF TRAINING ON EMPLOYEE PERFORMANCE
}

\author{
Debby Endayani Safitri \\ Universitas Muhammadiyah Prof Dr. Hamka, Indonesia \\ riby_42na@yahoo.com
}

\begin{abstract}
Abstrak
PT. Batam merupakan perusahaan manufaktur yang berada di pulau Batam dan bergerak di bidang minyak dan gas. PT. Batam adalah perusahaan yang selain membuat produk peralatan minyak dan gas juga memberikan pelayanan untuk perminyakan bagi perusahaan-perusahaan minyak di dunia, juga perusahaan-perusahaan minyak dan gas swasta dan perusahaan-perusahaan nasional minyak dan gas negara (BUMN). Tujuan penelitian ini adalah untuk mengetahui pengaruh pelatihan terhadap kinerja karyawan. Metode penelitian yang digunakan pada penelitian ini adalah metode kuantitatif deskriptif. Populasi penelitian ini adalah karyawan PT. Batam bagian departemen Machine Shop sebanyak 30 karyawan, dengan sampel penelitian sebanyak 30 karyawan. Teknik sampling yang digunakan adalah teknik sensus yaitu melakukan penelitian seluruh populasi yang ada. Hasil penelitian ini adalah bahwa ada pengaruh pelatihan terhadap kinerja karyawan PT. Batam.
\end{abstract}

Kata kunci: Sumber daya manusia, Pelatihan karyawan, Kinerja karyawan

\begin{abstract}
PT. Batam is a manufacturing company located on the island of Batam and engaged in oil and gas. PT. Batam is a company that in addition to producing oil and gas equipment products also provides oil services for oil companies in the world, as well as private oil and gas companies and national oil and gas (BUMN) companies. The purpose of this study was to determine the effect of training on employee performance. The research method used in this scientific work is descriptive quantitative method. The population of this research is employees of PT. Batam is part of the Machine Shop department with 30 employees, with a sample of 30 employees. The sampling technique used is a census technique that is conducting research on all existing populations. The results of this study are that there is an influence of training on the performance of employees of PT. Batam.
\end{abstract}

Keywords: Human resources, employee training, employee performance

\section{PENDAHULUAN}

PT. Batam adalah perusahaan manufaktur di sektor industri minyak dan gas yang terdiri dari beberapa industri besar mulai dari bidang industri pengeboran dan industri manufaktur penyediaan alat serta perlengkapan lainnya yang sangat dibutuhkan perusahaan- perusahaan minyak lainnya, banyak perusahaan manufaktur di bidang industri migas yang bersaing dalam menyiapkan alat atau perlengkapan pengeboran minyak, pengeboran tersebut bisa dilakukan di darat dan di laut. 
PT. Batam memproduksi alat untuk pengeboran bawah laut membutuhkan hasil produksi dengan kualitas yang tinggi, hal ini hanya bisa dilakukan melalui proses pengecekan kualitas oleh karyawan bagian atau divisi kualitas yang berkompeten memutuskan untuk mereject atau memutuskan bahwa barang yang diproduksi dalam kondisi bagus tidak cacat atau rusak dan sesuai dengan standar prosedur pembuatan barang (Standart Operating Procedure). PT. Batam juga memberikan pelayanan tenaga kerja ahli (professional servis) bagi perusahaan yang memerlukan tenaga ahli untuk dipekerjakan seperti melakukan instalasi, perbaikan, maintenan dan servis lainya. Mereka adalah pekerja lapangan yang sudah berpengalaman dan berkeahlian khusus dibidangnya.

PT. Batam adalah perusahaan minyak dan gas yang anak perusahaan dari XYZ international yang berpusat di London, Inggris. XYZ international mempunyai anak perusahaan di 60 negara di dunia, yang dibagi dalam wilayah-wilayah yaitu wilayah barat atau western region yang membawahi negara-negara yang berada di benua Amerika dan Amerika Latin berpusat di Houston, Amerika Serikat. Kemudian, Wilayah Timur atau Eastern Region yang membawahi nagara-negara Eropa dan Eropa Timur berpusat di Abeerden Skotlandia, sedangkan di Asia Pacific dan Middle East atau biasa disingkat dengan APME, berpusat di Singapura.

Perkembangan PT. Batam di seluruh dunia bermula pada tahun 1906, di Amerika Serikat atau tepatnya di San Pedro, California. Dimana Regan Forge Engineering mendirikan perusahaan yang membuat peralatan untuk industri minyak dan gas yang pada saat itu mulai berkembang. Kemudian pada tahun 1922 berdiri Gray Tool Company, yang didirikan di Houston Texas, yang juga bergerak dalam pembuatan peralatan untuk industri minyak dan gas. Tahun 1930 Ventura, California, perusahaan ini adalah perusahaan yang mengembangkan peralatan untuk pemeriksaan mutu dalam industri minyak dan gas merupakan salah satu pionir dalam industri pengeboran minyak dan gas.

Pada awal tahun 1960 an ketiga perusahaan tersebut bergabung menjadi XYZ international, dan ikut andil yang sangat besar dalam era emas perminyakan dunia tahun 60 an sampai 80 an, banyak sekali penemuan dalam bidang pengeboran minyak bawah laut (Deep Sea Drilling) dan memegang rekor dunia untuk pengeboran terdalam yaitu 150 meter di bawah 
permukaan laut pada tahun 1979. Perkembangan industri minyak dan gas yang sangat pesat maka pada tahun 1985, tepatnya 14 Juni, dimulailah pembangunan "PT. XYZ" Batam yang salah satu tujuannya untuk memenuhi kebutuhan akan komponen peralatan industri minyak dan gas.

Sumber daya manusia memiliki andil besar dalam menentukan maju atau mundurnya suatu perusahaan. Perusahaan untuk bisa mencapai kesuksesan maka diperlukan sumber daya manusia yang berkompeten. pada bidangnya dan memiliki kinerja yang bagus untuk mendukung pencapaian tujuan perusahaan. Beberapa aspek yang perlu diperhatikan oleh manajemen sumber daya manusia untuk memperoleh karyawan yang berkualitas dan berkompeten pada bidangnya serta dapat berkontribusi dalam pencapaian tujuan perusahaan adalah aspek pelatihan kerja dan kinerja karyawan.

Menurut Kaswan (2015) "Pelatihan kerja adalah proses meningkatkan pengetahuan dan keterampilan karyawan," selanjutnya menurut Simamora dan Hartatik (2014), "Tujuan dilakukannya pelatihan kerja adalah untuk memperbaiki kinerja karyawan yang tidak memuaskan karena kekurangan keterampilan."

\section{Tujuan Pelatihan}

Tujuan-tujuan pelatihan menurut Simamora dalam Hartatik (2014) adalah sebagai berikut:

a. Memperbaiki kinerja karyawan yang tidak memuaskan karena kekurangan keterampilan.

b. Memutakhiran keahlian para karyawan sejalan dengan kemajuan teknologi.

c. Mengurangi waktu pembelajaran bagi karyawan baru agar kompeten dalam pekerjaan.

d. Membantu memecahkan masalah operasional.

e. Mempersiapkan karyawan untuk promosi.

f. Mengorientasikan karyawan baru terhadap organisasi.

g. Memenuhi kebutuhan pertumbuhan pribadi.

\section{Manfaat Pelatihan}

Menurut Simamora dalam Hartatik (2014) terdapat beberapa manfaat yang didapat dari program pelatihan, yaitu sebagai berikut:

a. Meningkatkan kuantitas dan kualitas produktivitas. 
b. Mengurangiwaktu belajar yang diperlukan karyawan untuk mencapai standar kinerja yang dapat diterima.

c. Membentuk sikap, loyalitas, dan kerja sama yang lebih menguntungkan.

d. Memenuhi kebutuhan pertencanaan sumber daya manusia.

e. Mengurangi frekuensi dan biaya kecelakaan kerja.

f. Membantu karyawan dalam meningkatkan dan mengembangkan pribadi mereka.

Menghadapi era globalisasi saat ini PT. Batam harus mampu bersaing dengan perusahaan yang lain di dunia industri Minyak dan Gas dan demi kepuasan pelangganan maka dari itu PT. Batam merasa perlu untuk melakukan pelatihan kerja bagi karyawannya. Hal ini menunjukkan bahwa pelatihan kerja sangat penting bagi tenaga kerja agar dapat lebih menguasai pekerjaan yang di embannya dan sebagai upaya untuk mempersiapkan para tenaga kerja dalam menghadapi tugas perkerjaan yang dianggap belum dikuasainya serta sebagai upaya meningkatkan kinerja karyawan. Langkah ini dilakukan untuk menghindari kemungkinan terburuk dalam kemampuan dan tanggung jawab bekerja, sehingga tenaga kerja dapat menyelesaikan tugas dengan lebih efektif dan efisien serta mampu meningkatkan kinerjanya.

Sebagai seorang Operator Mesin (Machinist) yang bekerja di PT. Batam harus bekerja mengikuti prosedur kerja yang sudah ditetapkan dan bertanggung jawab dengan hasil kerja dan harus memastikan bahwa produk dalam kondisi bagus dan tidak ada cacat ataupun kerusakan, setelah dilakukan pengecekan produk oleh bagian divisi atau departemen kualiti. Setiap machinist harus mengetahui dan mengerti cara penggunaan mesin milling dan proses permesinan milling semua produk di PT. Batam sebelum melakukan tugas kerjanya di bagian departemen Machine Shop:

1. Operator Mesin (Machinist) bertanggung jawab untuk memeriksa MO (Material Order), Material PN (Part Number) dan program level revisi benar dan memberitahukan hasil aktifitasnya ke atasan atau Supervisornya.

2. Operator mesin memilih peralatan yang sesuai dengan ukuran sebelum di pasangkan di mesin milling.

3. Operator mesin harus memasang peralatan sesuai dengan permintaan program 
(Endmill, Drill, Tap, dll ).

4. Operator mesin harus melakukan review atau memeriksa hasil dari slot pertama.

5. Untuk hasil on size pertama $100 \%$ harus direview atau dicek oleh QC, dan melakukan function test (untuk batch pertama suatu project atau sesuai yang ditentukan di MO)

6. Karyawan harus selalu mengikuti instruksi kerja sebelum melakukan pekerjaannya. Untuk bisa menjadi seorang operator mesin (Machinist) yang handal dan ahli dalam pengoperasian mesin bubut karyawan Machine Shop departemen wajib mengikuti training (pelatihan) supaya dapat melakukan pekerjaan lebih aman. Kompetensi operator mesin bubut ini berdasarkan Permenakertrans No 38 tahun 2016.

Training yang wajib diikuti seorang machinist (Operator Mesin) adalah :

\section{Pelatihan (Training) Operator Jig Crane}

2. Pelatihan (Training) Operator Mesin Perkakas

Pengoperasian mesin yang tidak benar di departemen mesin shop karena karyawan yang belum atau tidak berkompeten sebagai Operator mesin bubut akan menyebabkan kerusakan hasil produk juga kerusakan mesin, oleh karena itu untuk menghindari hal yang bisa merugikan maka perusahaan perlu memberikan pelatihan untuk karyawannya sehingga karyawan menjadi trampil dalam bekerja dan meningkatkan kinerja karyawan itu sendiri.

Menurut Prawirosentono dalam Sinambela (2015) menyatakan, "Kinerja adalah hasil kerja yang dapat dicapai oleh seseorang atau kelompok orang dalam organisasi, sesuai dengan wewenang dan tanggung jawab masing-masing, dalam rangka upaya mencapai tujuan organisasi bersangkutan secara legal, tidak melanggar hukum dan sesuai dengan moral dan etika."

Menurut Bangun (2015) menyatakan, "Kinerja (performance) adalah hasil pekerjaan yang dicapai seseorang berdasarkan persyaratan-persyaratan pekerjaaan (job requirement)." Indikator kinerja meliputi quantity (jumlah pekerjaan), quality (kualitas pekerjaan), precision time (ketepatan waktu), attendance (kehadiran), team work (kemampuan kerjasama)

Kinerja adalah hasil kerja secara kualitas dan kuantitas yang dicapai oleh seorang pegawai dalam melaksanakan tugasnya sesuai dengan tanggung jawab yang diberikan 
kepadanya (Mangkunegara, 2015). Menurut Ratnasari (2017) Kinerja Karyawan adalah hasil kerja berupa kuantitas maupun kualitas setiap periode tertentu.

Menurut Dessler (2015) indikator untuk mengukur kinerja adalah sebagai berikut:

1. Kualitas kerja adalah akurasi, ketelitian, dan bisa diterima atas pekerjaan yang dilakukan.

2. Produktivitas adalah kuantitas dan efisiensi kerja yang dihasilkan dalam periode waktu tertentu.

3. Pengetahuan pekerjaan adalah keterampilan dan informasi praktis atau teknis yang digunakan pada pekerjaan.

4. Bisa diandalkan adalah sejauh mana seorang karyawan bisa diandalkan atas penyelesaian dan tindak lanjut tugas. Kelima,

5. Kehadiran adalah sejauh mana karyawan tepat waktu,mengamati periode istirahat atau makan yang ditentukan dan catatan kehadiran secara keseluruhan.

6. Kemandirian adalah sejauh mana pekerjaan yang dilakukan dengan atau tanpa pengawasan.

Jika perusahaan ingin mengoptimalkan produksi, memberikan pelayanan pasar global yang cepat dan tepat waktu hendaklah perusahaan menyediakan sumber daya manusia yang siap pakai dan mempunyai keahlian di bidangnya agar meningkatkan produktifitas sehingga karyawan bisa beradaptasi dengan berbagai situasi di dunia kerja di bidang dunia perminyakan dan gas. Produktifitas karyawan yang meningkat akan menguntungkan bagi perusahaan juga bagi pribadi karyawan sendiri. Dengan kinerja yang baik, produktifitas meningkat maka secara otomatis upah kerja sebagai balas jasa yang diterima juga meningkat.

Apabila kinerja karyawan turun, perusahaan akan mengalami penurunan penyediaan produksi barang dan ketepatan waktu produksi sehingga berdampak pada menurunnya elektabilitas perusahaan dalam persaingan pasar global. Bagi karyawan, penurunan kinerja berdampak pada penurunan produktifitas pekerjaan yang berpengaruh pada penurunan upah sebagai balas jasa. Berdasarkan hal tersebut, maka dapat disimpulkan bahwa lingkungan kerja dan stres kerja dapat mempengaruhi kinerja karyawan yang berdampak pada keberhasilan perusahaan. 


\section{Perumusan Masalah}

Adapun rumusan masalah diatas adalah apakah pelatihan berpengaruh terhadap kinerja karyawan PT. Batam?

\section{Tujuan Penelitian}

Tujuan dari penelitian ini adalah untuk mengetahui pengaruh pelatihan terhadap kinerja karyawan PT. Batam

\section{Metode Penelitian}

Metode penelitian yang digunakan pada penelitian ini adalah kuantitatif deskriptif. Menurut Sugiyono (2015) pengertian deskriptif adalah: "Penelitian deskriptif adalah penelitian yang dilakukan untuk mengetahui keberadaan variabel mandiri, baik hanya pada satu variabel atau lebih tanpa membuat perbandingan atau menghubungkan dengan variabel lainnya (variabel mandiri adalah variabel yang berdiri sendiri, bukan variabel independen, karena kalau variabel independen selalu dipasangkan dengan variabel dependen". Dalam penelitian ini, pendekatan deskriptif akan digunakan untuk

Populasi penelitian ini adalah karyawan PT. Batam bagian departemen Machine Shop sebanyak 30 karyawan, dengan sampel penelitian sebanyak 30 karyawan. Teknik sampling yang digunakan adalah teknik sensus yaitu melakukan penelitian seluruh populasi yang ada.

\section{Hasil dan Pembahasan}

Berdasarkan hasil pembahasan penelitian yang dilakukan di PT. Batam yang berjudul pengaruh pelatihan terhadap kinerja karyawan PT. Batam. Hasil penelitian yang diperoleh dari kuisioner yang telah diisi 30 orang karyawan departemen Machine Shop khususnya adalah Karyawan di departemen Machine Shop PT. Batam sebanyak 85 persen menyatakan bahwa pelatihan kerja sangat berpengaruh terhadap kinerja karyawan dan 15 persen menyatakan pelatihan kerja tidak berpengaruh terhadap kinerja karyawan

\section{Kesimpulan dan Saran}

\section{Kesimpulan}

Berdasarkan hasil penelitian dengan melakukan wawancara dan survey kepada 30 orang karyawan di departemen Machine Shop dapat disimpulkan bahwa Pelatihan berpengaruh 
terhadap kinerja karyawan PT. Batam.

\section{Saran}

Berdasarkan hasil penelitian dan observasi yang telah dilakukan pada karyawan di departemen Machine Shop PT. Batam maka saran yang diberikan kepada manajemen adalah sebagai berikut:

1. Pelatihan yang selama ini telah diberikan PT. Batam kepada karyawan operator mesin seperti training operator Jib Crane dan Training Operator mesin perkakas untuk tetap dipertahankan dan selalu diperbaharui. Pelatihan kerja kepada karyawan yang sesuai dengan kebutuhan di lingkungan tempat dia bekerja sangat berguna selain karyawan semakin ahli dalam pekerjaannya sehingga karyawan bisa melakukan pekerjaan dengan baik, ini bisa menghindari kerusakan barang atau produk yang dihasilkan, selain itu kerja karyawan lebih efektif dan efisien.

2. Karyawan yang sudah berbekal keahlian di bidang kerjanya hendaklah terus berusaha mengembangkan diri dengan terus belajar mengikuti perkembangan dari dunia kerja terutama karyawan di bidang perminyakan dan Gas sehingga ini bisa meningkatkan kinerja karyawan itu sendiri.

\section{Daftar Pustaka}

Dessler, G. (2015). Manajemen Sumber Daya Manusia. Jakarta: Index

Iswanto, Yun. (2017). Manajemen Sumber Daya Manusia. Jakarta: Penerbit Universitas Terbuka.

Hartatik, Puji Indah. (2014). Buku Praktis Mengembangkan SDM. Yogjakarta: Laksana.

Kaswan. (2015). Pelatihan dan Pengembangan Untuk Meningkatkan Kinerja SDM. Bandung: Alfabeta.

Kumara, I Wayan Sutya Edy. Utama, I Wayan Mudiartha. (2016). Pengaruh Pelatihan Terhadap Kinerja Karyawan Dengan Mediasi Kepemimpinan Pada Hotel Satriya Cottages Kuta Bali. E-Jurnal Manajemen Unud. Vol. 5, No. 3, 2016: 1399-1428.

Ratnasari, Sri Langgeng. 2017. Perencanaan Sumber Daya Manusia. Surabaya: Penerbit. Unggul Pangestu Nirmana. 
DIMENSI, VOL. 8 , NO. $2: 240-248$

JULI 2019

ISSN: 2085-9996

Sugiarti, Tuti Hartati, dan Hafniza Amir (2016). Pengaruh Pelatihan Kerja Terhadap Kinerja Karyawan Pada PT. Padma Ardya Aktuaria Jakarta. Jurnal Epigram. Vol. 13 No. 1 Apr. 